\title{
Intercropping Empower Reduces Insect Pests and Increases Biodiversity in Agro-Ecosystem
}

\author{
Sadia Afrin', A. Latif', N. M. A. Banu², M. M. M. Kabir'1, S. S. Haque1, M. M. Emam Ahmed1, \\ N. N. Tonu' ${ }^{3}$, M. P. Ali1 ${ }^{*}$ \\ ${ }^{1}$ Entomology Division, Bangladesh Rice Research Institute (BRRI), Gazipur, Bangladesh \\ ${ }^{2}$ Department of Entomology, Sher-e-Bangla Agricultural University, Dhaka, Bangladesh \\ ${ }^{3}$ Department of Plant Pathology, Sher-e-Bangla Agricultural University, Dhaka, Bangladesh \\ Email: *panna_ali@yahoo.com
}

How to cite this paper: Afrin, S., Latif, A., Banu, N.M.A., Kabir, M.M.M., Haque, S.S., Emam Ahmed, M.M., Tonu, N.N. and Ali, M.P. (2017) Intercropping Empower Reduces Insect Pests and Increases Biodiversity in Agro-Ecosystem. Agricultural Sciences, 8, 1120-1134.

https://doi.org/10.4236/as.2017.810082

Received: August 30, 2017

Accepted: October 20, 2017

Published: October 23, 2017

Copyright (C) 2017 by authors and Scientific Research Publishing Inc. This work is licensed under the Creative Commons Attribution International License (CC BY 4.0).

http://creativecommons.org/licenses/by/4.0/

\begin{abstract}
Currently insect pest management solely depends on chemical pesticide that continuously affects on environment, biodiversity, animal as well as human health. Outbreak of secondary insect pest is also the cost of pesticide use in field leading crop more vulnerable to more pests. These negative impacts of pesticides have provoked growing interest in the adoption of multi-function agricultural biodiversity that promote pest management, creating interesting challenge for traditional approaches to regulatory compliance. To address multi-function agricultural practice, we tested several intercropping systems with mustard and their effect on pest management. Our results revealed that intercropping systems mustard with onion, garlic, radhuni and coriander significantly reduced pest population over sole crop. However, intercropping mustard with wheat and gram increased pest population in mustard field. This result indicated that all crops are not suitable for intercropping system. Among the tested intercropping systems, mustard with onion and coriander significantly reduced branch and flower infestation and increased pod formation per plant. These four intercropping systems did not significantly affect on honeybee pollinator which are crucial for mustard crop yield. A significant linear relationship was also found between honeybee population and pod formation. Our results indicate that suitable intercropping system can be a potential multi-functional agricultural practice for pest management in mustard crop.
\end{abstract}

\section{Keywords}

Intercropping, Mustard Production, Insect Pest, Management, Biodiversity 


\section{Introduction}

Mustard (Brassica spp) is a major oilseed crop in the world which is grown in 53 countries including Bangladesh [1]. It is the most dominant oilseed crop in Bangladesh and covers alone $80 \%$ of the total area under oilseed crops [2]. The area under mustard cultivation in 2001 was 317,800 ha and reached 294,206 ha in 2014 along with total production increased from $238,000 \mathrm{t}$ to $296,000 \mathrm{t}$ [3]. Currently, Bangladesh is producing 0.36 million tons of edible oil but total requirement is far from actual demand (1.4 million tons) [4]. As a result, Bangladesh needs to invest to import edible oils from other countries for mitigating the demand for additional population and changing of dietary habits and nutritional awareness for total population. The investment for the import of mustard oil increased substantially from 2006 (2.42 million BDT) to 2014 (50.59 million BDT) [3]. This statement indicates that production of mustard crop urgently needs to be increased in Bangladesh. However, increasing of mustard cultivation area is difficult due to several reasons. Among them, climate change and insect pest infestation are the major obstacles to produce mustard crop.

Several insect pests are responsible for hampering mustard production and yield reduction in Bangladesh. To date, 38 insect pests are documented with rapeseed-mustard crop in India [5]. Among them, mustard aphid, Lipaphis erysimi Kalt. (Homoptera: Aphididae) is the most destructive pest in all the mustard growing regions of the country [6]. Both nymphs and adults of the mustard aphid infest the leaves, inflorescences and immature resulting poor pod setting and yield reduction [7]. They also induce growth of fungus that causes dirty and black pods and leaves [8]. L. erysimi causes $35.4 \%$ to $96 \%$ yield loss, $30.9 \%$ seed weight loss and 2.75\% oil loss [5] [9]. Application of control measure for this pest is necessary to reduce the yield loss and increase mustard production. However, currently farmers rely only on chemical insecticide for controlling this pest. This insecticide has tremendous effects on environment, biodiversity, human and animal health. To mitigate these problems, alternative approach is needed. So, there is a big challenge for agriculturist to explore alternative approaches to increase sustainable production [10].

Conventional farming practices contributed to increase yields during the $20^{\text {th }}$ century, but are today contested for their negative impact on the environment [11] [12], human health [13] and imbalance of ecosystem [14]. Industrialized monoculture systems, which are highly dependent on the use of external inputs such as agrochemicals (i.e. synthetized fertilizers, chemical pesticides, growth regulators), favoured the simplification of agroecosystems [15] [16]. In contrast, promoting functional biodiversity, which supports ecological processes, may allow agricultural systems to benefit from various ecosystem services, including nutrient cycling, soil structuration and pest control [17] [18]. One of the "agrobiodiversity strategies" to improve the sustainability of wheat production [19] is to increase plant species diversity at the field scale though intercropping designs 
[20] [21] [22].

Intercropping is an alternative practicable solution that combats crop insect pests [23] [24] [25] [26] [27]. It involves the cultivation of at least two crop species simultaneously in the same land [28] [29]. Mechanisms behind managing pest by intercropping system where the crops grow rather than main crops are not likely to be infested by the same insect pest [25]. It is a potential cultural practice for pest management since it diversifies crops in a given agro-ecosystem to reduce the population of insects and consequently their attack [30] [31] [32]. Research findings demonstrate that intercropping saves the target crop using several mechanisms. Non-host crops grown in intercropping can emit organic chemicals which adversely affect the pest insects, providing some degree of protection [27]. This might be happened due to the attention of biocontrol agents (natural enemies) of insect pests by the emission of organic chemicals or acts repelling the insect pest [33] [34] [35] [36] [37]. Sometimes mixed crop acts a barrier crop which hinders the movements of insect pests and thus the susceptible plant will suffer less [38].

Success for intercropping for pest management depends on the choice of associated crops and their additional valuation after harvest, to some extend knowledge of the farmers and mechanization practice used [10]. Several studies have been conducted and selected best intercropping practice with their associated crop that provide a successful crop production practice [23] [29] [31] [32] [39]. This study was undertaken to select best associated crop in mustard production by controlling major pest, $L$. erisimi.

\section{Materials and Method}

\section{Experimental site}

The experiment was conducted during the period from November 2012 to March 2013 at experimental farm of Sher-e-Bangla Agricultural University, Dhaka, Bangladesh. The location of the experimental site was $24^{\circ} 09^{\prime} \mathrm{N}$ latitude and $24^{\circ} 26^{\prime} \mathrm{E}$ longitude and an elevation of $8.2 \mathrm{~m}$ from sea level. The selected experimental plot was medium high land and the soil series was Tejgaon. The soil characterized by poor fertility and impeded by internal drainage. The $\mathrm{pH}$ of the experimental soil ranged from 5.5 to 6.2 .

\section{Experimental design and treatments}

The experiment was conducted using Randomized Complete Block Design (RCBD) with seven treatments. Each treatment was replicated three times. Mustard variety, Tori-7 was used for this experiment. The plant height of this variety ranges $60-75 \mathrm{~cm}$ and the life cycle is $75-75$ days when cultivated in Robi season. Treatments were mustard (Brassica spp) with $\mathrm{T}_{1}$-wheat (Triticum aestivum L.), $\mathrm{T}_{2}$-onion (Allium cepa L.), $\mathrm{T}_{3}$-garlic (Allium sativum $\mathrm{L}_{\text {. }}$ ), $\mathrm{T}_{4}$-coriander $(\mathrm{Co}$ riandrum sativum $\mathrm{L}$.), $\mathrm{T}_{5}$-radhuni (Trachyspermum roxburghianum $\mathrm{L}$ ), $\mathrm{T}_{6}$ gram (Cicer arietinum $\mathrm{L}$.) and $\mathrm{T}_{7}$-mustard alone.

Seed collection for intercropping 
The Mustard (Brassica napus var. Tori-7) was collected from Oilseed Research Center, Bangladesh Agricultural Research Institute, Gazipur. Wheat, onion (BARI onion-1), garlic (BARI Garlic-l) bulbs and coriander, radhuni, gram, seeds were collected from Spices Research Centre, Bangladesh Agricultural Research Institute, Gazipur.

\section{Experimental Procedure}

The experimental plot was opened in the first week of November 2012 with a power tiller, and was exposed to the sun for a week, after which the land was harrowed, ploughed and cross-ploughed several times followed by laddering to obtain a good tilth. Weeds and stubble were removed, and finally obtained a desirable tilth of soil for sowing of mustard Seeds. The unit plot size was $25 \mathrm{~m} \times 12$ $\mathrm{m}$. The distance between plots and blocks were $0.75 \mathrm{~m}$ and $1.0 \mathrm{~m}$, respectively. Row to row distance for mustard was $50 \mathrm{~cm}$. Similar distance was maintained when every seeds were sown. The fertilizers N, P, K, S, Zn and B in the form of Urea (300 kg/ha), TSP (180 kg/ha), MP (100 kg/ha), Gypsum (180 kg/ha), Zinc sulphate $(07 \mathrm{~kg} / \mathrm{ha})$ and borax $(15 \mathrm{~kg} / \mathrm{ha})$, respectively were applied. The entire amount of TSP, MP, Gypsum, Zinc sulphate and borax were applied during the final preparation of land. Urea was applied in two equal installments at final land preparation and at 30 days after seed sowing.

The seeds of mustard were sown in sole and in intercrop plot on 24 November 2012. The seeds of wheat, onion (bulb), garlic (bulb), coriander, radhuni, gram were sown on the same date. After establishment of seedlings, all other intercultural operations such as, thinning, weeding, irrigation were performed as per as when necessary for better growth and development of the mustard crop. Single irrigation was applied just once before flower initiation. Plots were provided with well arranged drainage facilities as prevention process of removing excess rain water if any. Weeding was done twice in the field to keep the plots free from weeds to ensured better growth and development of the crops. The newly emerged weeds were uprooted carefully at flowering stage by mechanical method.

\section{Data collection and analysis}

The data on the following parameters were recorded at different time intervals as given below: Total number of infested plants/plot, total number of branches/ plant, total number of infested branch/plant, total number of pod/plant, number of infested pod/plant, total number of flower/plant, number of infested flower/ plant, total number of Aphid (aphid/cm), number of honey bees (Aphis florae and Aphis indica), total number of seeds of five selected plants/plot, weight of total number of seeds/ 5 selected plant, total number of pods/ 5 selected plants, weight of pods/5 selected plants. Total number of infested plant was counted from each replication from randomly selected five plants. Total number of branch was counted from each replication from randomly selected five plants. Total number of infested branch was counted from total number of branch among selected five plants. Total number of flower was counted from each rep- 
lication from randomly selected five plants. Total number of infested flower was counted from total number of flower among selected five plants. Total number of pod was counted from each replication from randomly selected five plants. Average number of seed per plant was also counted and total seed weight was measured. Total number of aphid was counted from $1 \mathrm{~cm}$ from the inflorescense from each replication from randomly selected five plants. Number of honeybees (Apis florea and Apis indica) was recorded randomly from five selected plants.

Mustard was harvested at the maturity (93 days of sowing without disturbing the other inter crops) was done manually from each plot. Wheat, garlic and onion were harvested 102 days after sowing. The radhuni, coriander and gram were harvested at same date respectively. Different harvested crops of each plot was bundled separately, properly tagged and brought to laboratory floor. Care was taken for harvesting, threshing and also cleaning of mustard and other companion crops. The seeds were cleaned and finally the weight was recorded and converted into per hectare yield. Mustard of each plot was threshed separately, cleaned, sun dried, weighed and packed. Radhuni was threshed carefully because the grain is light and small in size. Mature onion and garlic bulbs were separated from the stem using sickle manually. The data collected from this work were subjected to analysis of variance followed by Fisher's L.S.D. test. The data were subjected to analysis of variance. Some sorts of data were also analyzed using ANOVA and means were compared by the Tukey's test. Significance was set at 0.05 . Data were transferred to logarithm scale or arcsine transformation in order to homogenize the variance. Linear regression analysis was also performed between honeybee population and pod formation/plant. All statistical analyses were done using the SPSS software version 16.0.

\section{Results}

\section{Impact of intercropping on aphid population and plant infestation}

The results showed that intercropping mustard with other six crops had a significant $(\mathrm{p}<0.05)$ effect on aphid population during the crop growing period. The pest incidence varied across the intercropping systems. The intercropping systems mustard with onion, mustard with coriander, mustard with garlic and mustard with radhuni showed lower population levels (14.98 to 15.40 per plant). The higher level of aphid population (19.07/plant) was recorded in mustard with gram $\left(\mathrm{T}_{6}\right)$ intercropping system which was statistically different from all other intercropping systems $(\mathrm{F}=, \mathrm{p}<0.05)$. Four intercropping systems over sole crop including onion, coriander, garlic and radhuni decreased significant percentage of aphid population but other two intercropping systems significantly increased percentage of aphid population (Figure 1). Mustard plants with intercropped crops were greatly influenced by the presence of aphid that has impact on crop yield.

Intercropping systems influenced plant infestation. The lowest percent branch infestation was found both in mustard with radhuni $\left(\mathrm{T}_{4}\right)$ and mustard with coriander $\left(\mathrm{T}_{5}\right)$ intercropping systems and having no significant statistical difference 


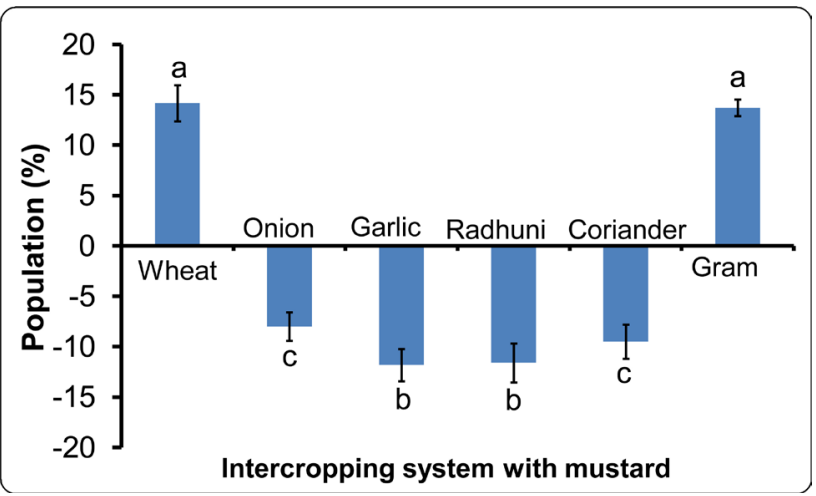

Figure 1. Effect of intercropping systems on aphid population, Lipaphis erysimi in mustard field. Error bars represent standard errors in each treatment. Values bearing the same letter are not significantly different using Fisher's LSD test at 5\% level.

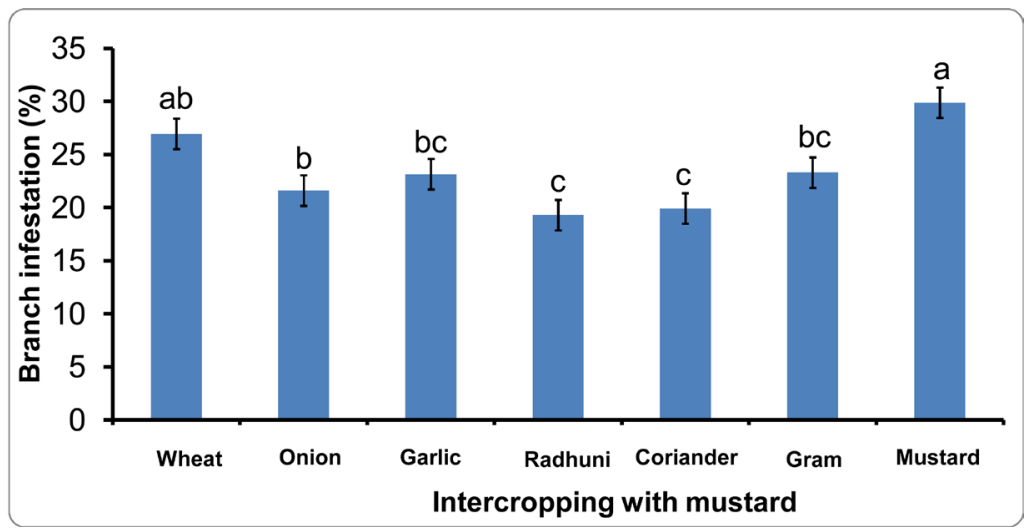

Figure 2. Effect of intercropping system on the branch infestation of mustard plant. Error bars represent standard errors in each treatment. Values bearing the same letter are not significantly different using Fisher's LSD test at 5\% level.

between them (Figure 2). Significant higher \% branch infestation was found in sole crop followed by $T_{1}, T_{2}$ and $T_{3}$ intercropping systems. The result indicates that intercropping of mustard with spices reduced aphid infestation over sole crops in the field. Flower is the most attractive part of mustard plant and highly infested by aphids in field. Significant variation was observed in terms of flower infested by aphid at different intercropping systems. The mustard with onion $\left(\mathrm{T}_{2}\right)$ intercropping system sowed the lowest \% of flower infestation. But the highest $\%$ of flower was infested by aphid was recorded in sole mustard crop (Figure 3). All tested intercropping systems showed significant lower pod infestation (\%) than that of sole cropping system (data not shown). Among the intercropping systems, $\mathrm{T}_{5}$ intercropping system showed the lowest pod infestation but statistically similar with $\mathrm{T}_{4}$ intercropping system (data not shown).

\section{Impact of intercropping on honeybee population}

Intercropping enhances biodiversity and interactions among plants, arthropods, mammals, birds and microorganisms providing in a more stable agroecosystem and a more efficient use of natural resources (such as space, water, 


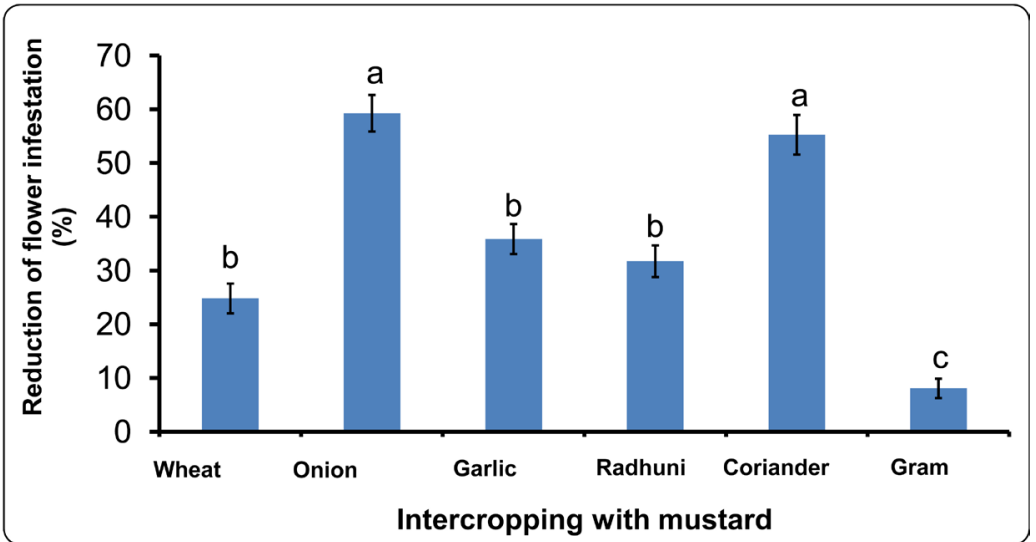

Figure 3. Effect of intercropping systems on flower infestation of mustard plant. Error bars represent standard errors in each treatment. Values bearing the same letter are not significantly different using Fisher's LSD test at 5\% level.

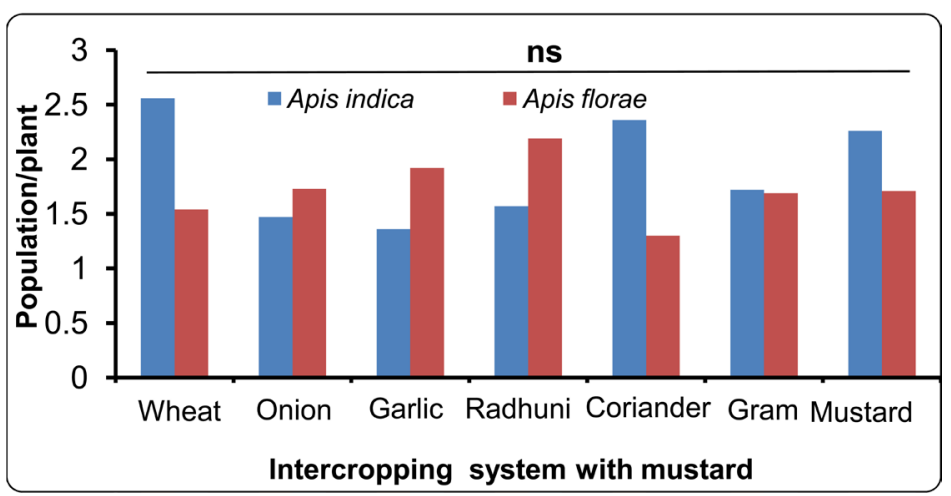

Figure 4. Effect of intercropping systems on honeybee population inn mustard crop. Error bars represent standard errors in each treatment. ns: Not significant at 5\% level. Means were separated using Tukey's Podthoc test.

sunlight and nutrients). Mustard is a cross pollination crop and sometimes its yield depends on the presence of natural pollinators such as honeybees. Therefore, intercropping can increase the number of pollinators in mustard field and thus improves crop yield. In our study we tested different intercropping systems with mustard and results revealed that mustard plants with intercropped the honeybee population that can alter crop yield. We documented two honeybee species, Apis indica and A. florae during mustard growing period in experimental plots. Results showed that the highest number of Apis indica was recorded in mustard with wheat $\left(\mathrm{T}_{1}\right)$ intercropping system and no significant variation was found among the intercropping systems (Figure 4). The lowest number of $A$. indica was recorded in mustard with onion and garlic intercropping systems. The highest number of $A$. florae was recorded (3.97) in mustard with radhuni intercropping system $\left(\mathrm{T}_{4}\right)$. On the other hand, the lowest number of $A$. florae was recorded in mustard with coriander $\left(\mathrm{T}_{5}\right)$ intercropped system.

\section{Crop yield}

Significant variation was observed in terms of number of branches/plant at 
different intercropping systems (Table S1). The highest number of branches/plant was recorded in mustard sole $\left(T_{7}\right)$ followed by $T_{6}$ (mustard with gram), $T_{3}$ (mustard with garlic) and $\mathrm{T}_{5}$ (mustard with coriander) intercropping system having no significant difference among them (Table S1). On the other hand, the lowest number of branch/plant was recorded in mustard with onion $\left(T_{2}\right)$ intercropping system. Significant variation was also observed in terms of flower at different treatments (Table S2). Results showed that the highest number of flower/branch was recorded in mustard with coriander $\left(\mathrm{T}_{5}\right)$ which was statistically similar in mustard with garlic $\left(\mathrm{T}_{3}\right)$ intercropping system. The lowest number of flower/branch was recorded in mustard with wheat $\left(T_{1}\right)$ intercropped combinations. Number of pods/plant is one of seed components of mustard. Highest number of pod/plant was recorded in mustard with onion $\left(\mathrm{T}_{2}\right)$ intercropping system which was statistically similar in mustard with coriander $\left(\mathrm{T}_{5}\right)$ and lowest number of pod/plant was recorded in mustard with gram $\left(\mathrm{T}_{6}\right)$ (Figure 5). Treatment of intercropping mustard with onion caused a significant increase in number of seeds/plant ( $\mathrm{g}$ ) compared to other treatments (Figure 6). Lowest amount of seeds/plant was recorded in mustard with gram intercropping system. Number of pod formation increased with the increased of honeybee population in crop field. There was a significant linear correlation found between pod formation and honeybee population (Figure 7, $\mathrm{F}=51.55 ; \mathrm{p}=0.001$ ). Intercropping systems also increased honeybee population in mustard field that indicated that some intercropping systems indirectly increased the yield of mustard crop.

\section{Discussion}

Aphid population was documented from all intercropping systems including sole crop and induction or deduction of \% population was calculated over the sole crop. Two intercropping systems mustard with wheat and with gram increased \% aphid population over sole crop and other four intercropping systems decreased aphid population (\%) in mustard field (Figure 1). These results

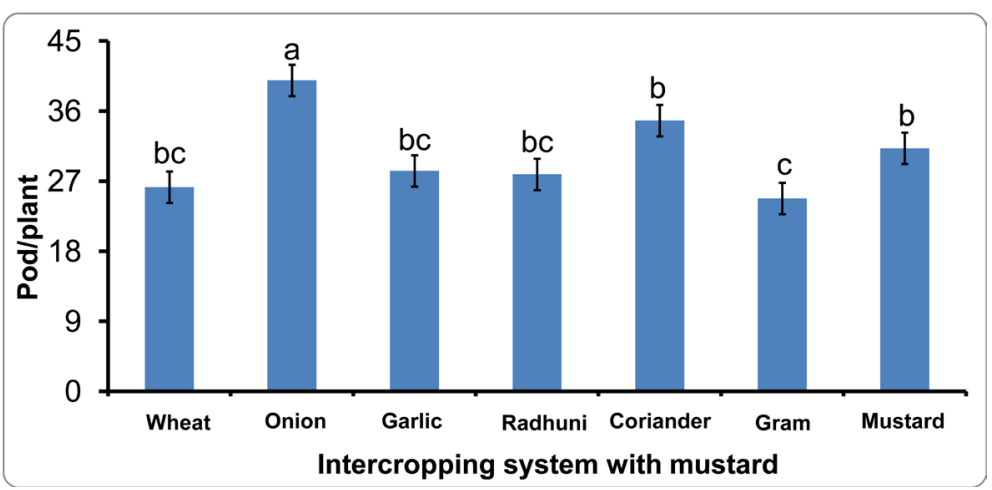

Figure 5. Effect of intercropping systems on pod formation in mustard plant. Error bars represent standard errors in each treatment. Values bearing the same letter are not significantly different using Fisher's LSD test at 5\% level. 


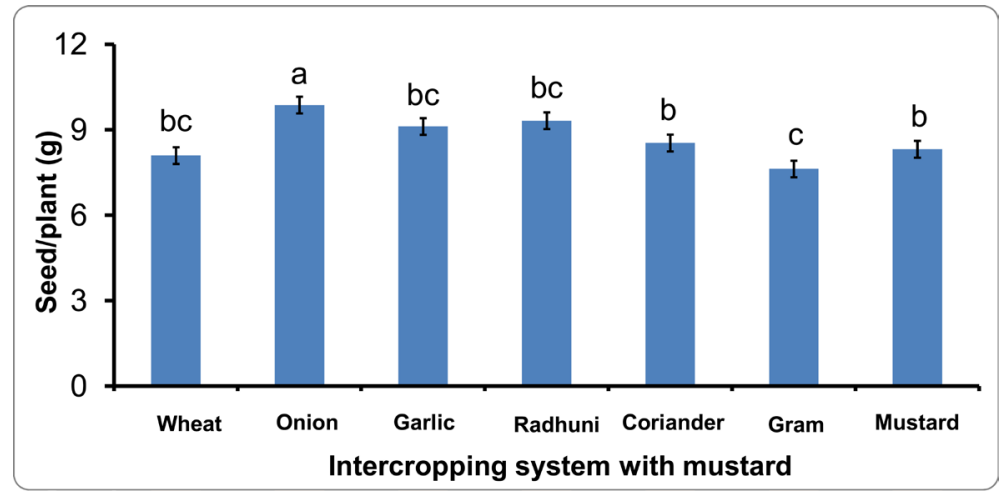

Figure 6. Effect of intercropping systems on seed/plant (g) in mustard crop. Error bars represent standard errors in each treatment. Values bearing the same letter are not significantly different using Fisher's LSD test at 5\% level.

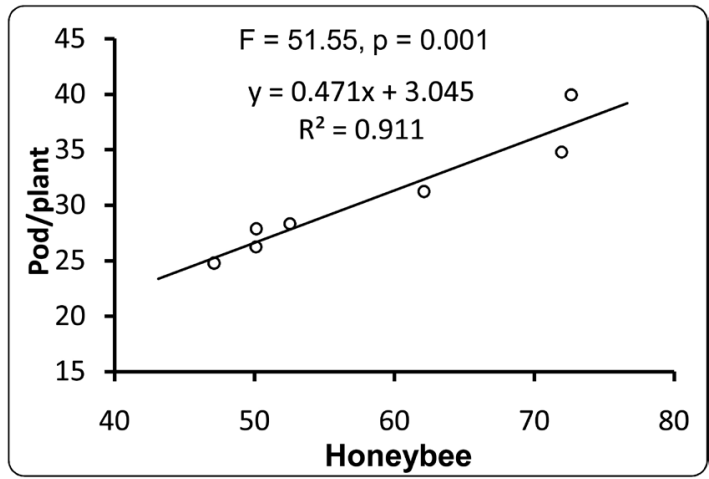

Figure 7. Relationship between honeybee population and pod formation/plant in mustard crop.

indicate that all intercropping systems are not suitable for insect pest management and studies are necessary for selection of best companion crop as an intercrop in relation to pest management. The mustard field in monoculture showed a smaller number of plants not attacked after the test from the field in intercropping with onion, garlic, radhuni, coriander. L. erysimi intensely attacked the mustard in monoculture leaving few plants, branches and flowers. This may be happened due to the fact that insects use volatile compounds to find the hosts and this cue can be more effective in monoculture field because the host could release volatile organic compounds [27]. Moreover, it was observed that in areas with mixed cultures (mustard and onion/garlic/coriander/gram), few plants/ braches/flowers were infested and at the harvesting stage, many mustard plants remained non-infested. The intercropping with mustard onion has a direct effect on the aphid, L. erysimi. This effect can be connected to emission of toxic volatile organic compounds or repellent to $L$. erysimi. The onion also can mask volatile organic compounds released by mustard and insect usually follows these volatiles for their host recognition. Onion plants emit sulfur organic compound named thilos and this compound provides several protective mechanisms mentioned above [40]. 
Our study revealed that intercropping systems mustard with wheat and gram increased aphid population over sole crop (Figure 1). This may be happened due to companion crops because companion crop, wheat itself acts as a host for aphid [41]. Intercropping with onion, garlic, coriander and radhuni significantly reduced aphid population (Figure 1). This was happened due to companion crops since they can act as repellents or barrier for movement of aphid population. Companion crops in intercropping system hinder the movements of insect pests and thus the main crop will suffer less damage [38]. Non-host crops that are grown in intercropping system also can emit organic chemicals which adversely affect the pest insects [27]. Other explanation can be applicable that reduction of pest population can be done due to attraction of biocontrol agents (natural enemies) of insect pests by the emission of volatile organic compound or acts repelling the insect pest [33] [34] [35] [36] [37]. In our study, data of natural enemies were not collected, however we can hypothesize that intercropping system enhanced biocontrol agents that reduced pest population in mustard crop. Dhaliwal and Arora [42] reported that pearl millet under intercropping enhanced number of parasitoid and predators. Sometimes intercropping system reduced up to $30 \%$ crop pest by increasing natural enemy effect [24]. In this way, intercropping systems can protect crop from pest infestation. Debra and Misheck [43] reported that intercropping cabbage crop with onion and garlic reduced the incidence of insect pest significantly. Particularly intercropping with wheat and garlic reduced aphid population from wheat field [44] and onion is usually used as control of aphid in intercropping system [45]. Besides these, similar to our findings were found in other many scientific studies [18] [32] [46] [47] [48] [49]. In our study, intercropping with mustard and coriander also showed significant pest population decreased over the sole crop (Figure 1). Similar result was found when mustard grown with coriander [50]. It may be happened due to emission of organic volatile compound by the coriander crop that acts as repellent of aphid or attraction of biocontrol agents of aphid.

In our study, intercropping systems did not significantly influenced the population of honeybee in mustard field. Visiting honeybee or other pollinators is important for mustard yield. Intercropping system will not affect the visiting of pollinators in mustard field. Our results showed that intercropping system influenced the pod formation per plant. Intercropping system mustard with onion showed significant higher pod/plant (Figure 5). Higher amount of seed/plant was also recorded in mustard with onion intercropping system (Figure 6). This may be happened due to higher pod formation/plan and lower flower infestation. Our study showed that intercropping system mustard with onion reduced flower infestation (Figure 3) which enhanced higher pod formation (Figure 5). Besides the main crop production, intercropping system also enhanced other crop yield that can maximize the production per unit land. Wszelaki [51] stated that the practice of intercropping can make benefits in a crop production system by decreasing insect pest infestation, lowering external inputs, enhancing biodi- 
versity, increase yield and reduce economic risk.

Based on our experimental results, it can be mentioned that multiple crop species grown in a single land increase biodiversity and encourage natural enemies. Developing mutual interactions misguide insects for host detection, reducing insect pests, lowering pest infestation and lowering external inputs. Plantation of multiple crops exploits different environmental niches, enhancing the total productivity per unit of land, providing financial diversification, as well as lowering the financial risk in case of target crop failure.

\section{Conflict of Interest}

Authors declared that they have no conflict of interest.

\section{References}

[1] Boomiraj, K., Chakrabarti, B., Aggarwal, P.K., Choudhary, R. and Chander, S. (2010) Assessing the Vulnerability of Indian Mustard to Climate Change. Agriculture, Ecosystems \& Environment, 138, 265-273. https://doi.org/10.1016/j.agee.2010.05.010

[2] Miah, M.A.M., Afroz, S., Rashid, M.A. and Shiblee, S.A.M. (2015) Factors Affecting the Adoption of Improved Varieties of Mustard Cultivation in Some Selected Sites of Bangladesh. Bangladesh Journal of Agricultural Research, 40, 363-379. https://doi.org/10.3329/bjar.v40i3.25411

[3] BBS (2016) Yearbook of Agricultural Statistics of Bangladesh 2014. Bangladesh Bureau of Statistics, Dhaka, Bangladesh.

[4] Mallik, M.S.A. (2013) Quality Seed Production of Oilseed Crops: An Overview. Paper Presented in the Workshop on "Modern Techniques for Quality Seed Production of Oilseed Crops". Oilseed Research Centre, Bangladesh Agricultural Research Institute, Gazipur.

[5] Bakhetia, D.R.C. and Sekhon, B.S. (1989) Insect-Pests and Their Management in Rapeseed-Mustard. Journal of Oilseeds Research, 6, 269-299.

[6] Das (2002) Ecology and Diversity of Agricultural Crop Infesting Aphid (Homptera; Aphidae) in Bangladesh. Journal of Aphidology, 16, 51-57.

[7] Saho, S.K. (2012) Incidence and Management of Mustard Aphid (Lipaphis erysimi Kaltenbach) in West Bengal. Plant Protection Science Journal, 4, 20-26.

[8] Awasthi, V.B. (2002) Introduction to General and Applied Entomology. Scientific Publisher, Jodhpur, 266-271.

[9] Singh, P.K. and Premchand (1995) Yield Loss due to Mustard Aphid, Lipaphis erysimi (Kalt.) in Eastern Bihar Plateau. Journal of Applied Zoology Research, 6, 97-100.

[10] Lopes, T., Hatt, S., Xu, Q., Chen, J., Liu, Y. and Francis, F. (2016) Wheat (Triticum aestivum L.) Based Intercropping Systems for Biological Pest Control. Pest Management Science, 72, 2193-2202. https://doi.org/10.1002/ps.4332

[11] Krebs, J.R., Wilson, J.D., Bradbury, R.B. and Siriwardena, G.M. (1999) The Second Silent Spring? Nature, 400, 611-612. https://doi.org/10.1038/23127

[12] Gibbons, D., Morrissey, C. and Mineau, P. (2015) A Review of the Direct and Indirect Effects of Neonicotinoids and Fipronil on Vertebrate Wildlife. Environmental Science and Pollution Research, 22, 103-118. 
https://doi.org/10.1007/s11356-014-3180-5

[13] Baldi, I., Cordier, S., Coumoul, X., Elbaz, A., Gamet-Payrastre, L., Le Bailly, P., et al. (2013) Pesticides: Effets surla santé. INSERM, Institut national de la santé et de la recherche médicale, Paris.

[14] Jeyasankar, A. (2012) Antifeedant, Insecticidal and Growth Inhibitory Activities of Selected Plant Oils on Black Cutworm, Agrotis ipsilon (Hufnagel) (Lepidoptera: Noctuidae). Asian Pacific Journal of Tropical Disease, 2, 347-351. https://doi.org/10.1016/S2222-1808(12)60179-0

[15] Kremen, C., Iles, A. and Bacon, C. (2012) Diversified Farming Systems: An Agroecological, Systems-Based Alternative to Modern Industrial Agriculture. Ecology and Society, 17, 44. https://doi.org/10.5751/ES-05103-170444

[16] Malézieux, E. (2012) Designing Cropping Systems from Nature. Agronomy for Sustainable Development, 32, 15-29. https://doi.org/10.1007/s13593-011-0027-z

[17] Altieri, M.A. and Rosset, P. (1996) Agroecology and the Conversion of Large-Scale Conventional Systems to Sustainable Management. International Journal of Environmental Studies, 50, 165-185. https://doi.org/10.1080/00207239608711055

[18] Zhang, L., van der Werf, W., Zhang, S., Li, B. and Spiertz, J.H.J. (2007) Growth, Yield and Quality of Wheat and Cotton in Relay Strip Intercropping Systems. Field Crops Research, 103, 178-188. https://doi.org/10.1016/j.fcr.2007.06.002

[19] Costanzo, A. and Bàrberi, P. (2014) Functional Agrobiodiversity and Agroecosystem Services in Sustainable Wheat Production. Agronomy for Sustainable Development, 34, 327-348. https://doi.org/10.1007/s13593-013-0178-1

[20] Hauggaard-Nielsen, H., Ambus, P. and Jensen, E.S. (2001) Interspecific Competition, N Use and Interference with Weeds in Pea-Barley Intercropping. Field Crops Research, 70, 101-109. https://doi.org/10.1016/S0378-4290(01)00126-5

[21] Malézieux, E., Crozat, Y., Dupraz, C., Laurans, M., Makowski, D. and Ozier-Lafontaine, H. (2009) Mixing Plant Species in Cropping Systems: Concepts, Tools and Models. Agronomy for Sustainable Development, 29, 43-62. https://doi.org/10.1051/agro:2007057

[22] Poggio, S.L. (2005) Structure of Weed Communities Occurring in Monoculture and Intercropping of Field Pea and Barley. Agriculture, Ecosystems \& Environment, 109, 48-58. https://doi.org/10.1016/j.agee.2005.02.019

[23] Rao, M.S., Rama Rao, C.A., Srinivas, K., Pratibha, G., Vidya Sekhar, S.M., Sree Vani, G. and Rizk, A.M. (2012) Effect of Strip-Management on the Population of the Aphid, Aphis craccivora Koch and Its Associated Predators by Intercropping Faba bean, Vicia faba L. with Coriander, Coriandrum sativum L. Egyptian Journal of Biological Pest Control, 21, 81-87.

[24] Baliddawa, C.W. (1985) Plant Species Diversity and Crop Pest Control. An Analytical Review. International Journal of Tropical Insect Science, 6, 479-487. https://doi.org/10.1017/S1742758400004306

[25] Baidoo, P.K., Mochiah, M.B. and Apusiga, K. (2012) Onion as a Pest Control Intercrop in Organic Cabbage (Brassica oleracea) Production System in Ghana. Sustainable Agriculture Research, 1. https://doi.org/10.5539/sar.v1n1p36

[26] Sharaby, A., Abdel-Rahman, H. and Sabry, S. (2015) Moawad1 Intercropping System for Protection the Potato Plant from Insect Infestation. Ecologia Balkanica, 7, 87-92.

[27] Sulvai, F., Chaúque, B.J.M. and Macuvele, D.L.P. (2016) Intercropping of Lettuce and Onion Controls Caterpillar Thread, Agrotis ípsilon Major Insect Pest of Let- 
tuce. Chemical and Biological Technologies in Agriculture, 3, 28. https://doi.org/10.1186/s40538-016-0079-Z

[28] Kahn, B. (2010) Intercropping for Field Production of Peppers. Horticulture Technology, 20, 530-532.

[29] Konar, A., Singh, N.J. and Paul, R. (2010) Influence of Intercropping on Population Dynamics of Major Insect Pests and Vectors of Potato. Journal of Entomological Research, 3, 151-154.

[30] Degri, M.M., Mailafiya, D.M. and Mshelia, J.S. (2014) Effect of Intercropping Pattern on Stem Borer Infestation in Pearl Millet (Pennisetum glaucum L.) Grown in the Nigerian Sudan Savannah. Advances in Entomology, 2, 81-86.

https://doi.org/10.4236/ae.2014.22014

[31] Pimentel, D., Hepperly, P., Hanson, J., Douds, D. and Seidel, R. (2005) Environmental, Energetic, and Economic Comparisons of Organic and Conventional Farming Systems. Bioscience, 55, 7-15.

[32] Vaiyapuri, K., Amanullah, M.M., Rajendran, K. and Sathyamoorthi, K. (2010) Intercropping Unconventional Green Manures in Cotton: An Organic Approach for Multiple Benefits: A Review. Asian Journal of Plant Sciences, 9, 223-226. https://doi.org/10.3923/ajps.2010.223.226

[33] Khan, Z.R., Chiliswa, P., Ampong-Nyarko, K., Smart, L.E., Polaszek, A., Wandera, J. and Mulaa, M.A. (1997) Utilisation of Wild Gramineous Plants for the Management of Cereal Stemborers in Africa. Insect Science and Its Application, 17, 143-150. https://doi.org/10.1017/S1742758400022268

[34] Landolt, P.J., Hofstetter, R.W. and Biddick, L.L. (1999) Plant Essential Oils as Arrestants and Repellents for neonate Larvae of the Codling Moth (Lepidoptera: Tortricidae). Environmental Entomology, 28, 954-960. https://doi.org/10.1093/ee/28.6.954

[35] Song, B., Tang, G., Sang, X., Zhang, J., Yao, Y. and Wiggins, N. (2013) Intercropping with Aromatic Plants Hindered the Occurrence of Aphis citricola in an Apple Orchard System by Shifting Predator-Prey Abundances. Biocontrol Science and Technology, 3, 381-395. https://doi.org/10.1080/09583157.2013.763904

[36] Letourneau, D.K., Armbrecht, I., Rivera, B.S., Lerma, J.M., Carmona, E.J. and Daza, M.C. (2011) Does Plant Diversity Benefit Agroecosystems? A Synthetic Review. Ecological Applications, 21, 9-21. https://doi.org/10.1890/09-2026.1

[37] Dassou, A.G. and Tixier, P. (2016) Response of Pest Control by Generalist Predators to Local-Scale Plant Diversity: A Meta-Analysis. Ecology Evolution, 6, 1143-1153. https://doi.org/10.1002/ece3.1917

[38] Parker, J.E., Rodriguez-Saona, C., Hamilton, G.C. and Snyder, W.E. (2013) Companion Planting and Insect Pest Control. INTECH Open Access Publisher.

[39] Shalaby, S. and Fouad, A.H. (2016) Effect of Intercropping Agroecosystem on the Population of Black Legume Aphid, Aphis craccivora Koch and Yield of Faba Bean Crop. Journal of Entomology and Zoology Studies, 4, 1367-1371.

[40] Mann, R.S., Mann, R.S., Rouseff, R.L., Rouseff, R.L., Smoot, J.M., Castle, W.S. and Stelinski, L.L. (2011) Sulfur Volatiles from Allium spp. Affect Asian Citrus Psyllid, Diaphorina citri Kuwayama (Hemiptera: Psyllidae), Response to Citrus Volatiles. Bulletin of Entomological Research, 101, 89-97. https://doi.org/10.1017/S0007485310000222

[41] Malschi, D., Ivas, A.D. and Kadar, R. (2013) Integrated Management of Wheat Aphids and Leafhoppers: Suitable Control Methods in Transylvania. Romanian 
Agricultural Research, No. 30, 317-328.

http://www.incda-fundulea.ro/rar/nr30/rar30.39.pdf

[42] Dhaliwal, G.S. and Arora, R. (1996) Principles of Insect Pest Management. National Agriculture. Technology Information Centre, Ludhiana.

[43] Debra, K.R. and Misheck, D. (2014) Onion (Allium cepa) and Garlic (Allium sativum) as Pest Control Intercrops in Cabbage Based Intercrop Systems in Zimbabwe. ISO 690 .

[44] Zhou, H.B., Chen, J.L., Yong, L.I.U., Francis, F., Haubruge, E., Bragard, C., Sun, J. and Cheng, D.F. (2013) Influence of Garlic Intercropping or Active Emitted Volatiles in Releasers on Aphid and Related Beneficial in Wheat Fields in China. Journal of Integrative Agriculture, 12, 467-473. https://doi.org/10.1016/S2095-3119(13)60247-6

[45] Saidi, M. and Itulya, F.M. (2006) Effect of Intercropping Collard with Beans or Onions on Aphid Populations and Yields of Collard under High Altitude Conditions in Kenya. Tanzania Journal of Agricultural Sciences, 7, 56-66.

[46] Wang, W.L., Liu, Y., Ji, X.L., Wang, G. and Zhou, H.B. (2008) Effects of Wheat-Oilseed Rape Intercropping or Wheat-Garlic Intercropping on Population Dynamics of $\mathrm{Si}$ tobion avenae and Its Main Natural Enemies. Chinese Journal of Applied Ecology, 19, 1331-1336.

[47] Cai, H.J., Li, S.Y., Ryall, K., You, M.S. and Lin, S. (2011) Effects of Intercropping of Garlic or Lettuce with Chinese Cabbage on the Development of Larvae and Pupae of diamondback Moth (Plutella xylostella). African Journal of Agricultural Research, 6, 3609-3615

[48] Xiao, X., Cheng, Z., Meng, H., Khan, M.A. and Li, H. (2012) Intercropping with Garlic Alleviated Continuous Cropping Obstacle of Cucumber in Plastic Tunnel. Acta Agriculturae Scandinavica, Section B-Soil \& Plant Science, 62, 696-705. https://doi.org/10.1080/09064710.2012.697571

[49] Karavina, C., Mandumbu, R., Zivenge, E. and Munetsi, T. (2014) Use of Garlic (Allium sativum) as a Repellent Crop to Control Diamondback Moth (Plutella xylostella) in Cabbage (Brassica oleraceae var. Capitata). Journal of Agricultural Research, 52, 4 .

[50] Tiwari, M.C.P. and Goel, R. (2005) Effect of Intercropping on the Population, Dynamics of Insect Pests and Yield of Mustard. Shashpa, New Delhi, 12, 106-110.

[51] Wszelaki, A. (2014) Trap Crops, Intercropping and Companion Planting: The University of Tennessee. Institute of Agriculture. Department of Plant Sciences Extension W235-F.

https://utextension.tennessee.edu/publications/Documents/W235-F.pdf 


\section{Supplementary Tables}

Table S1. Effect of intercropping system with mustard crop on plant and branch infestation by aphid.

\begin{tabular}{ccccc}
\hline Treatments & $\begin{array}{c}\text { Total number of } \\
\text { infested plant/plot }\end{array}$ & $\begin{array}{c}\text { Total number of } \\
\text { branch/plant }\end{array}$ & $\begin{array}{c}\text { Number of aphid infested } \\
\text { branch/plant }\end{array}$ & $\begin{array}{c}\text { Branch } \\
\text { infestation (\%) }\end{array}$ \\
\hline $\mathrm{T}_{1}$ & $1.69 \mathrm{~b}$ & $7.39 \mathrm{~cd}$ & $1.98 \mathrm{~b}$ & $26.95 \mathrm{ab}$ \\
$\mathrm{T}_{2}$ & $1.33 \mathrm{~d}$ & $6.80 \mathrm{~d}$ & $1.47 \mathrm{~b}$ & $21.62 \mathrm{~b}$ \\
$\mathrm{~T}_{3}$ & $1.67 \mathrm{~b}$ & $8.51 \mathrm{ab}$ & $2.03 \mathrm{~b}$ & $23.15 \mathrm{bc}$ \\
$\mathrm{T}_{4}$ & $1.42 \mathrm{~cd}$ & $7.77 \mathrm{bc}$ & $1.50 \mathrm{~b}$ & $19.30 \mathrm{c}$ \\
$\mathrm{T}_{5}$ & $1.50 \mathrm{c}$ & $8.23 \mathrm{abc}$ & $1.64 \mathrm{~b}$ & $19.92 \mathrm{c}$ \\
$\mathrm{T}_{6}$ & $1.75 \mathrm{~b}$ & $8.88 \mathrm{a}$ & $2.02 \mathrm{~b}$ & $23.31 \mathrm{bc}$ \\
$\mathrm{T}_{7}$ & $2.82 \mathrm{a}$ & $8.97 \mathrm{a}$ & $2.68 \mathrm{a}$ & $29.88 \mathrm{a}$ \\
$\mathrm{CV}$ & $5.43 \%$ & $6.57 \%$ & $17.24 \%$ & $14.08 \%$ \\
$\mathrm{LSD}_{0.05}$ & 0.15 & 0.94 & 0.56 & 5.75 \\
\hline
\end{tabular}

Values in the same column accompanied by the same letter(s) are not differ significantly $(\mathrm{p}=0.05) . \mathrm{T}_{1}=$ Mustard + Wheat, $\mathrm{T}_{2}=$ Mustard + onion, $\mathrm{T}_{3}=$ Mustard + garlic, $\mathrm{T}_{4}=$ Mustard + radhuni, $\mathrm{T}_{5}=$ Mustard + coriander, $\mathrm{T}_{6}=$ Mustard + gram, $\mathrm{T}_{7}=$ Sole mustard .

Table S2. Effect of intercropping systems with mustard crop on flower infestation by aphid.

\begin{tabular}{ccccc}
\hline Treatments & $\begin{array}{c}\text { Number of } \\
\text { flowers/infested } \\
\text { branch }\end{array}$ & $\begin{array}{c}\text { Number of aphid } \\
\text { infested flower/ } \\
\text { infested branch }\end{array}$ & $\begin{array}{c}\text { Flower } \\
\text { infestation } \\
(\%)\end{array}$ & $\begin{array}{c}\text { \% decrease of flower } \\
\text { infestation over sole } \\
\text { crop }\end{array}$ \\
\hline $\mathrm{T}_{1}$ & $4.73 \mathrm{c}$ & $3.42 \mathrm{~cd}$ & $72.30 \mathrm{bc}$ & $24.82 \mathrm{~b}$ \\
$\mathrm{~T}_{2}$ & $5.36 \mathrm{bc}$ & $2.10 \mathrm{e}$ & $39.17 \mathrm{~d}$ & $59.27 \mathrm{a}$ \\
$\mathrm{T}_{3}$ & $6.86 \mathrm{ab}$ & $4.23 \mathrm{abc}$ & $61.66 \mathrm{~cd}$ & $35.88 \mathrm{~b}$ \\
$\mathrm{~T}_{4}$ & $6.32 \mathrm{abc}$ & $4.15 \mathrm{~b}$ & $65.66 \mathrm{c}$ & $31.73 \mathrm{~b}$ \\
$\mathrm{~T}_{5}$ & $7.18 \mathrm{a}$ & $3.09 \mathrm{~d}$ & $43.03 \mathrm{~d}$ & $55.26 \mathrm{a}$ \\
$\mathrm{T}_{6}$ & $5.77 \mathrm{abc}$ & $5.10 \mathrm{a}$ & $88.38 \mathrm{ab}$ & $8.10 \mathrm{c}$ \\
$\mathrm{T}_{7}$ & $5.53 \mathrm{bc}$ & $5.03 \mathrm{ab}$ & $96.17 \mathrm{a}$ & - \\
$\mathrm{CV}$ & $16.11 \%$ & $10.48 \%$ & $14.74 \%$ & $16.39 \%$ \\
$\mathrm{LSD}_{0.05}$ & 1.70 & 0.93 & 22.49 & 15.17 \\
\hline
\end{tabular}

Values in the same column accompanied by the same letter(s) are not differ significantly $(\mathrm{p}=0.05) . \mathrm{T}_{1}=$ Mustard + Wheat, $\mathrm{T}_{2}=$ Mustard + onion, $\mathrm{T}_{3}=$ Mustard + garlic, $\mathrm{T}_{4}=$ Mustard + radhuni, $\mathrm{T}_{5}=$ Mustard + coriander, $\mathrm{T}_{6}=$ Mustard + gram, $\mathrm{T}_{7}=$ Mustard (control). 